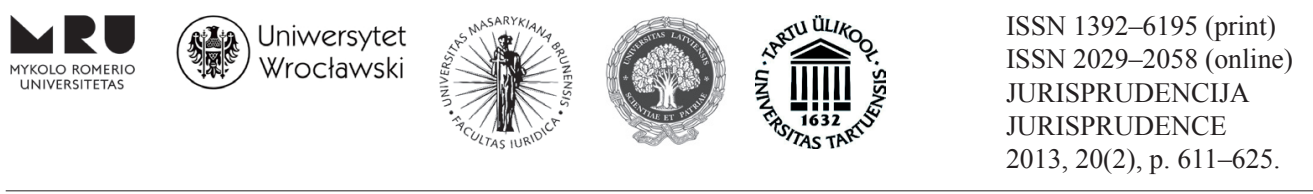

\title{
MATERIAL LIABILITY OF PUBLIC SERVANTS IN LITHUANIA: THEORY AND PRACTICE
}

\author{
Violeta Kosmačaitè, Vidmantas Jurgaitis \\ Mykolas Romeris University, Faculty of Law, \\ Institute of Constitutional and Administrative Law \\ Ateities 20, LT-08303 Vilnius, Lithuania \\ Telephone (+370 5) 2714545 \\ E-mail: violetak@mruni.eu; vidmantas.j@kpmpc.lt \\ Received on 17 December, 2012; accepted on 27 May, 2013 \\ doi:10.13165/JUR-13-20-2-13
}

Abstract. Legal acts of the Republic of Lithuania establish several types of material liability of workers engaged in labour (professional) relations: material liability applied pursuant to the Labour Code of the Republic of Lithuania (hereinafter referred to as the LC) and material liability applied pursuant to the Law on Public Service of the Republic of Lithuania (hereinafter referred to as the LPC).

In the present article, theoretical and practical aspects of material liability of Lithuanian public servants for material damage caused are analysed. The authors of the article study the conditions for the application of the material liability and identify the main circumstances that must be determined in applying this type of legal compulsion. Furthermore, the authors investigate the relation between the material and disciplinary liabilities, study the limits of the application of labour law norms (that regulate material liability of employees) and civil law norms (regulating personal civil liability) in professional legal relations, identify the means and procedure for solving disputes arising in the application of the material liability.

Practical mistakes in the application of the material liability of public servants and violations are analysed on the basis of a rather sparse case-law of the Supreme Administrative Court of Lithuania related to the material liability.

Keywords: public service, public servant, material liability, damage. 


\section{Introduction}

Novelty and relevance of the topic. In the general sense, material liability applied in labour relations, which in the theory of law is also referred to as substantial, is defined as 'mutual duty of employers and employees to compensate for pecuniary (material) damage caused by a violation of the terms of employment agreement'. ${ }^{1}$ Considering the significance of mutual liability of the parties to labour (professional) relations unquestionable, the author analyse the institute of the material liability of one of the parties to service relations, i.e. public servant as a person performing official functions.

The principle of the material liability of public sector employees is directly related to Article 42 of the Law on Public Administration of the Republic of Lithuania (hereinafter referred to as the LPA) which stipulates that pecuniary and non-pecuniary damage resulting from illegal acts of entities ${ }^{2}$ of public administration is compensated in accordance with the procedure set forth in the Civil Code (hereinafter referred to as the CC) and other laws. The LPC is a specific legal act that sets forth the material liability of public servants in detail: as provided in Article 2, public service is based on the principle of responsibility for the decisions made, while the principle of responsibility is considered to be one of the most important public servants professional conduct principles, which means that public servants are personally liable for their decisions and are to give an account to the society; Articles 31(1)-33 concretise the regulation of this institute.

The topicality of the application of the material liability may be approached from different perspectives. Even though this type of liability is not new in public service professional legal relations, its importance continues to grow.

Firstly, the topicality is conditioned by complex regulation of this institute, as in the application of the material liability the norms of several branches of law must be combined and delimited. Civil liability, material liability of employees working under employment agreements and public servants are separate; however, there exists an obvious connection in terms of the application of law. In the application of the material liability, a rather unclear situation emerges: in the LPS, the legislator repeats only a part of the LC articles related to the material liability; thus, it is possible to claim that such regulation is aimed at establishing a finite regulation of the material liability of public servants, because otherwise the question arises what would be the reason to repeat the norms of the LC that may be applied in public service under Article 5 of the LPS.

On the other hand, the topic is particularly relevant taking into consideration the practical problem. The problem is that the case-law of the Supreme Administrative Court of Lithuania (hereinafter referred to as the SACL) related to the application of this type of liability is rather sparse, which, in its turn, is conditioned by it being very rarely applied in the activity of public administration entities. This allows identifying several

1 Vaišvila, A. Theory of Law. Vilnius: Justitia, 2009, p. 468.

2 Under Article 2 Part 2 of the LPS an entity of public administration is an institution, agency, official, public servant or any other natural or legal person authorised by laws to engage in public administration. 
preconditions for the application of the material liability being 'unpopular': firstly, in the legal relations of the Lithuanian public service, there exists no actual practical need to apply public servants' material liability as almost no material damage is ever caused; secondly, in the application of the material liability, no law application and interpretation problems arise, legal regulation is clear and causing no controversy; thirdly, regulation of the material liability is ambiguous and 'poor', thus employers are not willing to apply legal norms regulating this type of legal compulsion and use the situation created by the fact that an employer, under the LPS, has a right but not an obligation to apply material liability to an employee for material damage caused. The abovementioned preconditions encourage analysing the institute of the material liability of public servants in greater detail.

To the knowledge of the authors, no in-depth legal-scientific research about the material liability of public servants based on case-law analysis and complex evaluation of regulation has been carried out in Lithuania. ${ }^{3}$

The aim of the present article is to reveal the specific features of the material liability of public servants as an independent type of liability as well as to analyse and evaluate the problem aspects of its legal regulation and application.

The object of the research is legal regulation and application of the material liability.

The tasks of the research are the following: 1) to analyse the boundaries of the application of labour law and civil law norms in the process of the application of the material liability of civil servants; 2) to study the specificity of the circumstances that must be determined in applying material liability of public servants as well as the possible solutions of the disputes arising in the process of the application of the material liability; 3 ) to evaluate the relation of the material liability to disciplinary liability.

The methods of the research: the method of document analysis was applied for the evaluation of laws as well as sub-statutory legal acts and case-law acts which control the regulation of the material liability of public servants; the systemic analysis method allowed to reveal the relation of the material liability to the disciplinary liability of public servants as well as evaluate the cases of the application of labour law and civil law norms in the realisation of the material liability; the analytic-critical method was applied for the determination of the gaps in the regulation of the material liability and its application and the generalisation method was used to draw conclusions at the end of the article.

3 Studies of administrative regulation of the Lithuanian public service have been carried out by Jolanta Palidauskaite, Alfonsas Laurinavičius, Andrius Valickas. General analysis of material liability (without focusing on practical problems of its application and a review of case-law) is presented in the commentary on the LPS by Rasa Budbergyte, Alvydas Šakočius and Dainius Žilinskas as well as in a textbook of Lithuanian administrative law written by a group of authors (Lithuanian Administrative Law. The General Part. Vilnius: Mykolas Romeris University, 2005, p. 442-445.) 


\section{Specific features of the regulation of material liability of public servants}

Material liability of public servants is regulated by the norms of various branches of law; therefore, it may be treated as a complex legal institute. While applying material liability, one often refers not only to the norms of administrative law (i.e. the LPS), but also to the norms of labour law (i.e. the LC) and civil law (i.e. the CC).

The LPS stipulates only several general conditions for the emergence of the material liability; however, nothing is mentioned about the application of other conditions of the emergence of the material liability that are applied in civil or labour legal relations. On the other hand, Article 246 of the LC stipulates other conditions ${ }^{4}$ necessary for the emergence of the material liability that are more numerous than the ones listed in Article 32 Part 1 of the LPS. As concluded by the SACL, such faulty regulation of public service, on the basis of Article 4 Part 5 of the Law on Administrative Proceedings of the Republic of Lithuania (hereinafter referred to as the LAP), allows applying the provisions of the LC as much as the determination of the conditions for the emergence of the material liability and its application is concerned ${ }^{5}$. Thus, on the basis of these arguments and Article 5 of the LPS, under which laws and other legal acts regulating labour relations and social guarantees are applied to public servants as long as their status and social guarantees are not regulated under the LPS, the provisions of the LC allow filling in the gaps in the regulation of the material liability of the public servants.

As the evaluation of the status of civil law norms in respect of the material liability is concerned, noteworthy is the fact that in the general sense the material liability is claimed to have originated from civil liability, which, under Article 6.245 of the CC, implies a pecuniary obligation, one party of which has the right to claim for compensation of damages (damage) or demand payment of the penalty (fine, interest), and the other party is bound to make compensation for damages (damage) caused or pay the penalty (fine, interest). The material liability of public servants is directly related to pecuniary obligation that is believed to have originated from delict legal relations, as one of the main conditions for the application of this liability is unlawful activity of a public servant, while the unlawful activity and refrainment from acting are related to a breach of the norms of law.

Another thing to be stressed is that the material liability is related to damage, while the conception of damage is inseparable from and originated from civil legal regulation. In public service relations the conception of damage must be interpreted

4 Article 246 of the LS sets forth that liability is incurred 'when all the following conditions are present:

1) damage has been caused; 2) damage has been caused through illegal activity; 3) there is a causal relationship between an illegal activity and damage; 4) the offender is guilty; 5) the offender and the victim were in a labour relationship during the violation of law; 6) the resulting damage relates to work activities'.

5 Ruling of The Supreme Administrative Court of Lithuania of 27 June 2011 in Administrative Case No. $A^{438}-2120 / 2011$. 
pursuant to Article 6.249 of the CC. ${ }^{6}$ Despite other articles of the CC, of particular importance is Article 6.271 stipulating liability for damage caused by unlawful actions of institutions of public authority. This article is directly related to Article 33 of the LPS, under which damage resulting from illegal actions of a state or municipal institution or agency is compensated in accordance with the procedure established by the $\mathrm{CC}$, a state or municipal institution or agency that has compensated for the damage inflicted by a public servant has the right of regress with respect to the public servant.

To summarise, the application of labour law and civil law norms is an inseparable part of the application of the material liability of officers that allows filling in the gaps of legal regulation of this institute, while the boundaries of the application of the abovementioned branches of law depend on particular kind of the material liability and factual circumstances of a particular case of the material liability of a public servant. Thus, in the case of the application of the material liability to a public servant, the LPS is referred to in the first place. In cases, when a certain situation is not regulated by the LPS, under Article 5 of the LPS, the LC is followed. However, if the LC also does not establish the regulation of certain issues, the provisions of the $\mathrm{CC}$ are referred to because its Article 1.1 Part 3 stipulates that the provisions of this Code apply to labour relations to the extent when they are not regulated by special laws. Such regulation forces to closely follow the delimitation of these branches of law and certain succession of the application of legal norms. On the other hand, the LPS in its regulation of the material liability of public servants repeats only a part of the articles of Chapter XVII of the LC and some of the provisions of the $\mathrm{CC}$. In such a way, one may claim it is aimed at determining a finite regulation of the material liability of public servants, as it is not purposeful to transpose particular norms of the LC that may be applied in public service directly under Article 5 of the LPS. Otherwise, there arise problems with the clarification of the application of this article. In addition, the problem arise which provisions of the LC may automatically be realised in the case of the material liability of public servants, and which may not. Such a situation allows claiming that the LPS should distinguish only those material or process (procedural) norms of the material liability of public servants that reflect the actual need to establish exceptional (i.e. different from analogous relations in labour law) legal regulation of this institute.

\section{Conditions to be determined while applying material liability of public servants}

The LPS does not provide a definition of the material liability; it only states that public servants incur material liability for material damage caused to a state or municipal institution or agency (Article 28 of the LPS). In the present article, the authors do not

6 Under this Article, damage includes the amount of the loss or damage of property sustained by a person and the expenses incurred (direct damages) as well as the incomes of which a person has been deprived, i.e. the incomes he would have received, if unlawful actions had not been committed. 
aim at presenting a definition of the material liability ${ }^{7}$; however, the goal is to discuss the circumstances established by legal regulation that must be determined if the material liability of public servants is applied and that reflect the content of this liability.

The main conditions that must be determined in the application of the material liability of public servants are established in Article 32 Part 1 of the LPS: 1) damage must be caused to a state or municipal institution or agency; 2) activity of a public servant must be illegal and guilty; 3) material damage caused must be direct. With reference to the case-law of the SACL and Article 5 of the LPS, one may state that the list of conditions is not comprehensive and is to be supplemented by the points indicated in Article 246 of the LC.

Thus, in the application of the material liability of public servants one must determine:

1) whether damage was caused to a state or municipal institution ${ }^{8}$ or agency ${ }^{9}$. This circumstance shows which entity experienced material damage as a result of unlawful actions of a public servant. As a rule, such an entity usually is a public administration institution, in which the public servant, who incurs material liability, is employed. However, a logical analysis of this point allows stating that damage may also be caused to other institutions, i.e. government entity, in which the public servant, who incurs material liability, is not employed. A state or municipal administration entity gets the right to apply material liability, when a public servant by its direct activity causes damage to the entity of public administration or when it compensated for the damage caused to another person and gets the right of recourse to the public servant who caused damage.

2) whether the material damage caused was direct. In Article 32 Part 1 of the LPS, it is expressly stated what damage must be compensated, i.e. direct material damage. This regulation does not correspond to the regulation of the material liability established in the norms of labour law: under Article 257 of the LC, the amount of the damage to be compensated comprises direct losses and the income which has not been received. Following Article 6.249 Part 1 of the CC, damage includes the amount of the loss or damage of property sustained by a person and the expenses incurred (direct damages),

7 Material liability of public servants, taking into consideration the theories of the institute of liability, may be explained as a duty established by legal norms; as a sanction causing negative consequences for the person to whom the material liability is incurred; as a specific legal relation within the limits of which a sanction set forth in a regulatory act is realised. Finally, the material liability may be analysed in the contexts of positive and delict liability. Bagdanskis, a labour law specialist, suggests the following definition of the material liability: material liability is a pecuniary liability that emerges when one entity of labour relations causes material damage to another entity or, otherwise, violates his pecuniary interests by non-performance or inappropriate performance of his duties marked by the attributes of compensational or protective legal relations, aimed at full compensation for damage caused or to the extent set forth in labour laws by ensuring the balance of the interests of the entities of labour relations. Bagdanskis, T. Material Liability Problems in Labour Legal Relations. PhD Dissertation. Vilnius, 2005, p. 45.

8 Under Article 2 Part 5 of the LPS, an institution of public administration is a collegial or one-man entity of public administration authorised by laws to adopt administrative regulatory enactments.

9 Under Article 2 Part 6 of the LPS, an agency of public administration is a state or municipal budgetary agency authorised by laws to engage in public administration. 
as well as the incomes of which he has been deprived, i.e. the incomes he would have received, if unlawful actions had not been committed. Thus, it is possible to conclude that direct material damage is direct losses, which, under the $\mathrm{CC}$, may include loss or damage of property or expenses incurred, while damages are damage in the terms of money. The notion of 'incomes of which one has been deprived' that may be recovered from an employee under the LC is, in essence, not typical of public administration entities, as the main aim of their functioning is not directed towards reception of income. The SACL in its commentary on Article 32 Part 1 of the LPS indicated that the reference to direct material damage in this particular legal norm means that it is possible to compensate only for those damages (damage) of a state (municipal) institution that would have been avoided if the public servant had not acted illegally. ${ }^{10}$

3) whether the damage was caused as a result of illegal activity of a public servant (i.e. illegal activity or refrainment from acting of a public servant that becomes the cause of the emergence of material damage). The legality of the activity or refrainment from acting of a public servant must be evaluated in the context of legal acts regulating his/her activity. The evaluation of the illegality of the activity of an employee must be objective and comprehensive. If illegal activity is not determined, the question of the material liability should not be raised at all.

4) whether there is a relation of causality between illegal activity and damage. As neither the LPS nor the LC suggest the conception of the relation of causality, one must follow the regulation which is established in Article 6.247 of the CC. This Article stipulates that only those damages can be compensable which are related to actions (acting or refrainment from acting) giving rise to civil liability of the debtor in such a manner that the damages, taking into account their nature and that of the civil liability, can be imputed to the debtor as a result of his actions (acting or refrainment from acting). The SACL concludes that direct relation of causality between illegal activity and emergence of damage comprise one of the conditions for the emergence of the material liability, thus, a public servant is responsible for damage that is a direct result of illegal activity. The ruling also allows concluding that there may exist situations when illegal activity of a public servant may be treated only as a favourable condition for the emergence of damage, and such a relation between illegal activity and the emergence of damage is indirect; therefore, material liability is not applicable. ${ }^{11}$ Considering this position of the court, it is possible to conclude that indirect relation of causality, when certain activity of a public servant or refrainment from acting is only a condition for the emergence of damage and not the cause of the damage itself, cannot serve as grounds for the application of the material liability of public servants.

5) whether there exists the guilt of a public servant. Article 32 Part 1 of the LPS establishes a common principle of legal liability typical of the negative process of the application of legal norms, the essence of which is that a person may not be punished

10 Ruling of The Supreme Administrative Court of Lithuania of 23 October 2007 in Administrative Case No. $A^{11}-920 / 2007$.

11 Ruling of The Supreme Administrative Court of Lithuania of 25 November 2010 in Administrative Case No. $A^{261}-1531 / 2010$. 
without guilt. Under Article 6.246 Part 2 of the CC, the guilt of a public servant may manifest itself through intentional activity or negligence. While individualising material liability, the form of guilt determines the type of the material liability to be applied full or limited. In the case of intentional activity of a public servant, a requirement to compensate for all material damage caused to an entity of public administration is applied. Noteworthy is the fact that in administrative courts, while judging cases related to the application of the material liability, the evaluation of the principle of the presumption of guilt is ambiguous. In one of the cases, the SACL stated that for the legal relations in that particular case, the provisions of Article 21 of the LPS, which provides that a public servant must compensate for damage caused only by his illegal guilty act, should be applied. In their essence, the relation between parties are closer to labour law rather than to civil law, and, following the principles of labour law, the employer is to prove the existence of the conditions of the material liability, as the presumption of guilt of an employee is not established in laws. ${ }^{12}$ However, in another case, the SACL stated that the conditions of civil liability, i.e. the presumption of guilt, which is set forth in Article 6.248 of the CC, must be applied. These provisions cannot be applied pursuant to Article 4 Part 6 of the LAP, as neither the LPS nor the LD provides a definition of guilt as a condition for the compensation of material damage. This suggests that in the case of a denial of this presumption, the burden of proof shifts to the claimant ${ }^{13}$, as he did not provide evidence denying the existence of his guilt in terms of the indicated damage ${ }^{14}$. Regarding the opinion of the authors, one should follow the principle of the burden of proof placed on the person who applies material liability and the principle that a public servant is innocent unless proven otherwise; furthermore, this liability is applied for damage caused by professional actions and during the period of office, while in professional legal relations the employee is the weaker (financially as well as in the terms of authority) party to the relation.

6) whether the public servant is bound by labour (professional) legal relations with the aggrieved party. This attribute shows that there exists professional subordination between the public servant to whom the material liability is incurred and the person applying the material liability. Under the LPS, the material liability is applied by the person employing the public servant. To correspond to this status, the particular position the person should be working in is established on the basis of Article 10 of the LPS. The SACL in the application of norms regulating the material liability takes into consideration this requirement, as well. In an administrative case, where a question regarding the material liability of a statutory public servant was under discussion, the board of judges emphasised the boundaries of the application of the norms of the Statute of the Internal Service of the Republic of Lithuania and stated that it regulates material liability relations between an institution of internal affairs and an officer of the system of

12 Ruling of The Supreme Administrative Court of Lithuania of 3 November 2011 in Administrative Case No. $A^{63}-2899 / 2011$.

13 In this administrative case, the claimant was the public servant to whom material liability was incurred.

14 Ruling of The Supreme Administrative Court of Lithuania of 19 November 2010 in Administrative Case No. $A^{143}-1519 / 2010$. 
internal service working in that institution. Therefore, while applying this legal act, one must determine whether the material damage, the compensation of which is required on this legal ground, emerged in the course of professional legal relations, i.e. to ascertain the extent to which the emergence of the material damage is to be related to particular professional legal relations between two entities established in this legal norm. ${ }^{15}$

7) whether damage was caused while performing professional (public service) duties. This circumstance means that the material damage to an entity of public administration must be caused while performing professional duties by a public servant, i.e. performing the functions laid down in his/her position description. There may exist situations when damage may be caused not during the hours of office; in such cases, grounds emerge to apply other legal norms that allow ensuring the compensation of material damage experienced, i.e. civil and criminal liability.

To summarise the abovementioned circumstances, it should be stated that factual determination of these circumstances creates grounds for the emergence of the material liability of public servants. If any of them is missing at the moment of committing a violation, there are no grounds for the application of the material liability under the LPS.

Even though material liability is a completely individual type of legal liability, it has close connections to disciplinary liability. Article 28 of the LPS sets forth the cases when public servants incur disciplinary or material liability. It is important to stress that the material liability and the disciplinary liability are applied simultaneously. This means that a public servant may commit an act of misconduct in office, while non-performance or inappropriate performance of one's official duties may condition the emergence of material damage. However, Article 28 does not stipulate that for the material liability to be applicable, the damage must be caused by committing an act of misconduct in office. As the authors of the commentary to the LPS state, damage to a state or municipal institution or agency may be also caused when misconduct in office has been committed in the activity of a public servant. ${ }^{16}$

Differently from the material liability, the application of the disciplinary liability, set forth in the LPS, is quite explicitly regulated in the sub-statutory level. ${ }^{17}$ On the other hand, regarding the procedure for the compensation of material damage, only several articles of the LPS are intended. Such a regulatory situation creates ambiguities in practice; therefore, while applying material liability, the entities of public administration often imperatively apply legal acts regulating the procedure for disciplinary proceedings and the imposition and lifting of disciplinary sanctions. Such practice is faulty. ${ }^{18}$ The

15 Ruling of The Supreme Administrative Court of Lithuania of 13 April 2010 in Administrative Case No. $A^{143}-576 / 2010$.

16 Budbergyte, R.; Šakočius, A.; Žilinskas, D. Commentary on the Law on Public Service of the Republic of Lithuania. Vilnius: Lithuanian Institute of Public Administration, 2004, p, 152.

17 Resolution No. 977 of 25 June 2002 of the Government of the Republic of Lithuania 'On Approval of Rules for the Imposition of Disciplinary Sanctions to Public Servants'.

18 For example, under the LPS, disciplinary liability must be applied within one month after the day when an act of misconduct was brought to light, while material liability must be applied within one month after the day when the material liability was brought to light, but this does not mean that the same regulation must be applied and that the day of bringing to light should be related to the same legal circumstances. 
SACL has stated that the obligation to exercise disciplinary proceedings in the case of material damage is not established in laws; therefore, there is no grounds for claims that the legal relation of a dispute remains unregulated and another legal act of lower force should be applied on the basis of analogy. ${ }^{19}$ In a situation when the disciplinary as well as the material liability is incurred to a public servant, disciplinary proceedings are initiated in respect of an act of misconduct in office, while in respect of the material liability, an independent investigation of factual circumstances is carried out pursuant to the norms of the LPS. On the other hand, if material damage is caused by committing an act of misconduct in office, the investigation must be completed within one month after the day when the act of misconduct was brought to light. In one of administrative cases, the SACL, while considering the question of the material liability of a statutory public servant, has stated that if disciplinary proceedings are related to possible acts of misconduct which result in damage to property entrusted to officers for the performance of their official duties and one of the aims of the disciplinary proceedings is to find the person guilty of the damage, as it was the case in the situation under consideration, which refers to Article 32 Part 4 of the LPS regarding the deduction of compensation for the damage caused from the remuneration of the public servant, the disciplinary proceedings must be completed no later than within one month after the day when the act of misconduct was brought to light. ${ }^{20}$

\section{Problem of disputes regarding material liability, possible ways of their solution and jurisdiction}

In the application of the material liability, parties to this legal relation (i.e. the public servant to whom the material liability is incurred or the person applying the material liability, who, under Article 32 of the LPS, is the person who employed the public servant), pursuant to the LPS, have at their disposal procedural rights including the right to question the actions of another party or object to them and address a court. ${ }^{21}$ Such a possibility is regulated by:

- Article 32 Part 4 of the LPS, which stipulates that while applying material liability to a public servant, some part of it is deducted from the remuneration of the public servant following administrative procedure and the part of damage which is not compensated is to be recovered by bringing an action in court;

19 Ruling of The Supreme Administrative Court of Lithuania of 7 March 2008 in Administrative Case No. A502 - 304/2008.

20 Ruling of The Supreme Administrative Court of Lithuania of 8 February 2010 in Administrative Case No. $A^{146}-208 / 2010$.

$21{ }^{21}$ Such normative regulation identifies who may apply to the court: firstly, when a public servant to whom material liability is incurred applies to the court because of a violation of his/her rights or legitimate interests; secondly, when in implementing the procedure for the application of the material liability the person employing the person to whom the material liability is incurred applies to the court. 
- Article 32 Part 6 of the LPS, which stipulates that a public servant, disagreeing with the decision of the person, who has admitted him to office, concerning compensation for the damage caused to the state or municipal institution or agency, has the right to apply to the court;

- Article 33 Part 3 of the LPS, which stipulates that while applying solidary material liability to the head and members of a collegial state or municipal institution, disputes concerning compensation for damage are to be settled by court.

Such legal regulation allows claiming that legal acts do not establish any early extrajudicial way for the resolution of disputes arising from the application of the material liability. Thus, in such situations one cannot apply neither the provisions of Chapter XIX of the LC that regulate the procedure for the resolution of individual labour disputes and the use of labour dispute committees as a compulsory organ in labour relations nor the provisions regulating application to quasi-judicial institutions that resolve disputes arising from administrative legal relations. ${ }^{22}$

Therefore, in the case of a dispute regarding legal norms regulating the application of the material liability of public servants, the only way is the court; however, the abovementioned Articles do not clearly show to what court to apply - the court of general jurisdiction or administrative one. Article 32 Part 4, which defines the notion of a claim, also raises doubts. Considering the fact that pursuant to Article 22 of the LAP the main forms of addressing administrative courts are a complaint or an application and that claims are addressed to the courts of general jurisdiction only, a question of the jurisdiction of such cases arises.

In the decision of 18 August 2009 of the Special Board of Judges for the resolution of dispute regarding the jurisdiction of a case examined, the jurisdiction of a case dealing with the recovery of the compensation of material damage caused by a public servant by an institution in which the public servant works. The Board of Judges concluded that the notion of a claim, that is, first of all, typical of civil procedure law, used in the LPS, does not in itself create grounds to ascribe a case to the courts of general jurisdiction. Furthermore, the Board of Judges stated that the institute of the material liability of public servants is a part of the law regulating public service and, consequently, the relations of the material liability of public servants fall into the sphere of the legal relations of public service. ${ }^{23}$ Thus, one may conclude that the dispute related to the institute of the material liability of public servants originated from the sphere of professional relations and, thus, are ascribed to professional disputes ${ }^{24}$, while professional disputes, pursuant to Article 15 Part 1 Clause 5 of the LAP, are solved in administrative courts.

22 For example, Municipal Social Administrative Disputes Commission or the Chief Administrative Disputes Commission.

23 Decision of 18 August 2009 of the Special Board of Judges.

24 Under Article 2 Part 19 of the LAP, professional disputes are disputes arising between public servants having public administration authority and the administration related to the acquisition of the status of a public servant, change in the status or loss thereof and the application of disciplinary measures. It is obvious that Professional relations may be of various types: related to the employment and dismissal from work as well as motivation, application of liability, deprival of social guarantees, faulty calculation of the period of public service experience, etc. of a public servant. 
Meanwhile, an analysis of Article 2 Part 5 Clause 19 and Article 19 Part 2 Clause 4 of the LAP allows concluding that in administrative courts cases related to professional disputes are judged without the application of the procedure for an early extrajudicial hearing.

The use of the institute of the material liability of public servants may be relevant not only when a person works in a public service, but also in cases when he/she stops performing the duties of a public servant. In such situation, it is also important to choose the appropriate court for the resolution of the dispute. In the decision of 7 July 2005, the Special Board of Judges commented on the jurisdiction of a dispute in a case, where the claimant, an entity of public administration, addressed the court for the compensation of damage caused by a former statutory public servant. In this case the claimant stated that he addressed the defendant (a former police officer) for the compensation of damage caused to the entity of public administration, i.e. for a return of overpaid remuneration for annual leave; however, the defendant did not return the sum overpaid. The Board of Judges clarified that the questions of the case are related to the professional relations of the defendant as a former public servant having public administration authority and even if the dispute was related to the compensation for damage caused by a public servant, the case, pursuant to Article 15 Part 1 Clause 5 of the LAP, had to be heard in administrative court, as the institute of the material liability of public servants is a part of law regulating public service and such relations are to be ascribed to the category of public service relations. ${ }^{25}$

\section{Conclusions}

1. Material liability of public servants is realised by the complex application of the norms of administrative, labour and civil law; however, legal relations, which develop while applying the material liability to public servants, in their legal nature, are closer to labour law than to civil law. Such an application is determined by the regulation established in the norms of Article 5 of the LPS and Article 1.1 Part 3 of the CC, while the boundaries of the application of the abovementioned branches of law depend on the type of liability and factual circumstances of a particular case of the material liability of a public servant.

2. The LPS in its regulation of the material liability of public servants repeats only a part of the provisions of Chapter XVII of the LC regulating the material liability. In this way, it is aimed at establishing a finite regulation of the material liability of public servants, because otherwise it is not purposeful to transpose the particular norms of the LC that may be applied in public service under Article 5 of the LPS. Such regulation forces to closely follow the delimitation of these branches of law and certain succession of the application of legal norms and to emphasise that in the LPS there should be a clear distinction of only those material or procedural norms of the material liability of public

25 Decision of 18 July 2009 of the Special Board of Judges 'On the Jurisdiction of the Dispute Regarding the Compensation of Damage'. 
servants that reflect the actual practical need to establish exceptional legal regulation of this institute.

3. The material liability of public servants is a completely individual type of legal liability having close connections to disciplinary liability. The material liability and the disciplinary liability are often applied simultaneously, as the same guilty illegal act may comprise an act of misconduct in office, while non-performance or inappropriate performance of one's official duties may condition the emergence of material damage. However, damage to a state or municipal institution or agency may be also caused when there is no misconduct in office in the activity of a public servant.

\section{References}

Bagdanskis, T. Material Liability Problems in Labour Legal Relations. PhD Dissertation. Vilnius, 2005.

Budbergytè, R.; Šakočius, A.; Žilinskas, D. Commentary on the Law on Public Service of the Republic of Lithuania. Vilnius: Lithuanian Institute of Public Administration, 2004.

Civil Code of the Republic of Lithuania. Official Gazette. 2000, No. 74-2262.

Decision of 7 July 2005 of the Special Board of Judges 'On the Jurisdiction of the Dispute Regarding the Compensation of Damage'.

Decision of 18 August 2009 of the Special Board of Judges in case No. T-XX-57-09.

Labour Code of the Republic of Lithuania. Official Gazette. 2002, No. 64-2569.

Law on Administrative Proceedings of the Republic of Lithuania. Official Gazette. 1999, No. 13-308; 2000, No.85-2566.

Law on Public Administration of the Republic of Lithuania. Official Gazette. 1999, No. 601945.

Law on Public Service of the Republic of Lithuania. Official Gazette. 1999, No. 662130; 2002, No. 45-1708.

Resolution No. 977 of 25 June 2002 of the Government of the Republic of Lithuania 'On Approval of Rules for the Imposition of Disciplinary Sanctions to Public Servants'. Official Gazette. 2002, No. 45-1708.
Ruling of The Supreme Administrative Court of Lithuania of 23 October 2007 in Administrative Case No. $\mathrm{A}^{11}$ - 920/2007.

Ruling of The Supreme Administrative Court of Lithuania of 7 March 2008 in Administrative Case No. A502 - 304/2008.

Ruling of The Supreme Administrative Court of Lithuania of 23 November 2009 in Administrative Case No. A ${ }^{662}-1297 / 2009$.

Ruling of The Supreme Administrative Court of Lithuania of 8 February 2010 in Administrative Case No. A $\mathrm{A}^{146}-208 / 2010$.

Ruling of The Supreme Administrative Court of Lithuania of 13 April 2010 in Administrative Case No. A ${ }^{143}-576 / 2010$.

Ruling of The Supreme Administrative Court of Lithuania of 19 November 2010 in Administrative Case No. $\mathrm{A}^{143}-1519 / 2010$.

Ruling of The Supreme Administrative Court of Lithuania of 25 November 2010 in Administrative Case No. $A^{261}-1531 / 2010$.

Ruling of The Supreme Administrative Court of Lithuania of 27 June 2011 in Administrative Case No. $A^{438}-2120 / 2011$.

Ruling of The Supreme Administrative Court of Lithuania of 3 November 2011 in Administrative Case No. A A $^{63}$-2899/2011.

Vaišvila, A. Theory of Law. Vilnius: Justitia, 2009. 


\title{
LIETUVOS VALSTYBĖS TARNAUTOJŲ MATERIALINĖ ATSAKOMYBE்: TEORIJA IR PRAKTIKA
}

\author{
Violeta Kosmačaitè, Vidmantas Jurgaitis \\ Mykolas Romerio universitetas, Lietuva
}

Santrauka. Lietuvos Respublikos teisès aktai numato kelias darbo (tarnybos) santykiuose esančiu darbuotoju materialinès atsakomybès rüšis: materialinè atsakomybè, kuri yra taikoma pagal Lietuvos Respublikos darbo kodeksa (toliau - DK), ir materialinè atsakomybe, kuri yra taikoma pagal Lietuvos Respublikos valstybès tarnybos įstatyma (toliau - VTI).

Straipsnyje nagrinejjami Lietuvos valstybès tarnautojams už padaryta materialinę žala taikomos materialines atsakomybes teoriniai ir praktiniai aspektai. Straipsnio autoriai analizuoja materialinés atsakomybès taikymo salygas bei išskiria pagrindines aplinkybes, kurias bütina konstatuoti taikant šiq teisinès prievartos rüšş. Taip pat straipsnyje vertinamas materialines ir tarnybinès atsakomybiu santykis, tiriamos darbo teisés normu (reglamentuojančiu darbuotoju materialine atsakomybę) ir civilinès teises normu (reglamentuojančiu asmenu civiline atsakomybe) taikymo ribos tarnybiniuose teisiniuose santykiuose, nurodomi ginču, kylančiu materialinès atsakomybes taikymo metu, sprendimo büdai ir tvarka.

Straipsnio autoriai, išanalizave materialinès atsakomybès instituta, teigia, kad:

- valstybès tarnautoju materialine atsakomybe realizuojama kompleksiškai taikant administracines teises, darbo teisés ir civilinès teisès normas, tačiau teisiniai santykiai, susiklostantys taikant valstybeis tarnautojui materialinę atsakomybę, savo teisine prigimtimi yra artimesni darbo nei civilinei teisei. Toks taikymas suponuotas VTI 5 straipsnio ir Lietuvos Respublikos civilinio kodekso 1.1. straipsnio 3 dalies normose itvirtinto norminio reglamentavimo, o pastaruju šaku taikymo ribos priklauso nuo konkrečios materialines atsakomybès rüsies bei konkrečios tarnautojo materialinès atsakomybès bylos faktiniu aplinkybiu.

- VTI atkartoja tik dali DK nuostatu, reglamentuojančiu materialine atsakomybę. Manytina, kad taip siekiama nustatyti baigtini valstybes tarnautoju materialines atsakomybès reglamentavima, nes priesingu atveju nèra tikslinga perkelti konkrecias DK normas, kurios ir taip valstybès tarnyboje gali büti taikomos pagal VTI 5 straipsnị. Toks reguliavimas leidžia teigti, kad VT įstatyme turetu büti išskiariamos tik tos materialinés ar procedürinès valstybès tarnautoju materialinès atsakomybès normos, kurios atspindètu realu poreiki nustatyti išskirtini šio instituto teisini reguliavima, lyginant ji su analogišku teisiniu santykiu reguliavimu, nustatytu DK.

- valstybès tarnautoju materialine atsakomybe yra visiškai savarankiška teisinés atsakomybès rüšis, tačiau susijusi su tarnybine atsakomybe. Dažnai, taikant materialine atsakomybę, kartu taikoma ir tarnybinè, nes ta pačia kalta neteisèta veika valstybès tarnautojas gali padaryti tarnybinį nusižengima, o tarnybiniu pareigu neatlikimas arba netinkamas atlikimas gali büti ir materialinès žalos atsiradimo priežastis. Tačiau žala valstybès ir savivaldybès institucijai ar istaigai gali büti padaryta ir tuomet, kai valstybes tarnautojo padarytoje veikoje tarnybinio nusižengimo sudeties nèra. 
Reikšminiai žodžiai: valstybès tarnyba, valstybès tarnautojas, materialinè atsakomybè, žala.

Violeta Kosmačaitė, Mykolo Romerio universiteto Teisės fakulteto Konstitucinès ir administracinès teisès instituto lektorè. Mokslinių tyrimų kryptys: administracinio proceso teisès problemos, viešasis administravimas, valstybės tarnyba.

Violeta Kosmačaitė, Mykolas Romeris University, Faculty of Law, Institute of Constitutional and Administrative Law, Lecturer. Research interests: The problems of administrative procedural law, public administration, civil service.

Vidmantas Jurgaitis, Mykolo Romerio universiteto Teisès fakulteto Konstitucinès ir administracinès teisès instituto lektorius. Mokslinių tyrimų kryptys: administracinis teisinis reguliavimas.

Vidmantas Jurgaitis, Mykolas Romeris University, Faculty of Law, Institute of Constitutional and Administrative Law, Lecturer. Research interests: administrative legal regulation. 